\title{
Inside vs. Outside Lobbying: How the Institutional Framework Shapes the Lobbying Behavior of Interest Groups
}

\author{
FLORIAN WEILER ${ }^{1} \&$ MATTHIAS BRÄNDLI ${ }^{2}$ \\ ${ }^{1}$ University of Bamberg, Germany; ${ }^{2}$ University of Zurich, Switzerland
}

\begin{abstract}
Different types of interest groups use different lobbying strategies. In this paper, we investigate this already well-established hypothesis once more, but in addition we propose that the institutional framework of the country in which interest groups operate also influence their lobbying behavior. More specifically, it is shown that groups working in the interest of the public are better integrated into the policy making process when direct democratic instruments, such as referendums, occur regularly (as in Switzerland), than when referendums are the exception (Germany). We demonstrate that Swiss cause groups, often also referred to as public interest groups in the literature, use a more balance mix of insider and outsider strategies than their German peers, but also that this moderating effect cannot be found for specific interest groups such as industry groups or unions.
\end{abstract}

Keywords: interest group strategies, inside lobbying, outside, electoral institutions, direct democracy

Address for correspondence: Florian Weiler, University of Bamberg, Feldkirchenstraße 21, 96045 Bamberg, Germany. Phone: +49 (0) 951863 2805; E-mail: florian.weiler@uni-bamgerg.de 


\section{Introduction}

Political interest groups interact with policy makers, the public, and the media to communicate their points of view, and to influence the policy-making process. Such lobbying efforts consume valuable resources, and interest groups have to decide how to allocate them. The organizations studied in this paper are assumed to behave in a goal-oriented fashion, and we expect those audiences perceived by lobbying groups as being more important to be targeted more often. However, in this article we want to emphasize that lobbying behavior cannot be fully understood from a purely rationalistic point of view. Instead, we propose that contextual factors are crucial for how interest groups lobby. Specifically, we study the role the institutional environment plays for lobbying practices. We examine how this environment shapes the lobbying behavior of Swiss and German interest groups towards their four main targets of lobbying: parties, the government, the media and the general public. When parties and the government are targeted by interest organizations, the literature speaks of inside lobbying strategies or insider tactics. Trying to influence the policy making process via the media or public support is called outside lobbying (Beyers, 2004). We create an index to measure how heavily an organization relies on inside lobbying strategies compared to outsider tactics, and propose hypotheses as to why organizations should rely more or less on one or the other.

The paper contributes to the growing literature on interest strategies (e.g. Schattschneider, 1960; Schlozman \& Tierney, 1986; Gais \& Walker, 1991; Kollman, 1998; Lowery \& Gray, 2004). More specifically, this paper builds on earlier work on how the group type of an organization influences its lobbying behavior (see Beyers, 2004; Binderkrantz, 2008; Binderkrantz \& Krøyer, 2012; Dür \& Mateo, 2013). Our major contribution to this body of literature is the proposition that the lobbying behavior of groups is conditional on the institutional setting. Furthermore, other than most previous researchers, we focus on the national level. According to Kriesi et al. (2007), "the national level remains the dominant focus for strategic interventions of [different] types of actors", including interest organizations. We propose that in settings where direct democratic instruments are used regularly, as is the case in Switzerland, the lobbying behavior of different group types will converge. In other words, they will act in a more similar manner to each other than in countries where these instruments are not available. Specifically, groups that tend to depend more on outsider tactics are expected to be better integrated into the policy making process when referendums are likely. In contrast, groups that prefer insider strategies when not faced with the threat of referendums need to increase their use of outsider strategies when direct democracy plays a role. So far, the discussion of the role institutions play in shaping lobbying behavior has remained mostly theoretical (e.g. Dür, 2008), or focused on the institutions of the European Union (Beyers, 2004). This consideration of electoral institutions 
influencing lobbying behavior is, to our knowledge, new and has not been examined before. In this article, this argument is laid out more clearly and tested empirically.

The relevance of this paper lies in the potential impact different electoral institutions have for lobby groups and their behavior, but also for a political system as a whole. Dür \& Mateo (2013) note that "studying the determinants of interest group strategies is important because if such groups' choice of strategy heavily depends on the institutional opportunity structures, an institutional reform that favors one strategy may bias the representation of interests in that political system". Our findings below indicate, for instance, that direct democratic instruments facilitate public interest groups' direct access to policy-makers. Because the implementation (or intensification) of direct democratic instruments is currently being discussed in many countries, including Germany, one of the study subjects of this paper, knowing the potential implications of such a reform is essential. Furthermore, it is of importance to know how countries' institutional settings influence lobbying behavior even when no institutional changes are considered. If the argument that direct democracy leads to a better integration of a wider array of groups into the policy making process is valid, then questions arise about the bias of the policy-making process towards powerful interests in representative democracies. For the analysis we rely both on Ordinary Least Square (OLS) and Heckman selection models. The next section lays out the theoretical arguments and derives hypotheses thereof. Then the research design and the empirical findings are presented. The last section concludes.

\section{Strategies of Groups in Different Institutional Settings}

The aim of lobby groups is to influence public policy. The two main lobbying strategies are gaining access (insider lobbying) and going public (outsider lobbying). The aim of gaining access is to influence policy makers directly, so they support - and if possible adopt - the policy preferred by the interest group. Going public, on the other hand, is a more indirect strategy, which aims at putting pressure on policy makers via media campaigns, or by mobilizing citizens and staging protests.

Information plays a crucial part for insider lobbying. Politicians' time and resources are scarce, and they suffer from time constraints and a resulting lack of adequate information. The information provided by interest organizations represents a shortcut for policy-makers to (usually well-edited and summarized) expert knowledge, and is therefore generally appreciated. Political interest organization are well endowed with information in their particular field(s) of activity (Truman, 1951; Potters \& van Winden, 1990; Lohmann, 1995; Bouwen, 2004; Dür \& 
Mateo, 2012). Interest organizations therefore play an important part in most modern democratic systems.

However, policy makers are also aware that interest groups pursue their own goals, and that these goals are not necessarily congruent with their own (Hansen, 1991). Thus, it is rational for policy makers to invite interest organizations with contrasting views to consult with them, and to also consider concerns of groups using outside strategies (Beyers, 2004). Interest organizations are aware of this, and therefore use outside lobbying as a second way to influence the policy making process. In addition, Kriesi et al. (2007) note that, according to their observations, attempts to influence policies are most efficient when multiple tactics are used. For these reasons, most political interest groups use a mix of inside and outside strategies, instead of specializing in either of them (Baumgartner \& Leech; 1998, Mahoney, 2007).

How much interest groups invest in the two tactics is shaped by various factors. The factor under investigation in this paper, i.e. how the institutional environment influences the lobbying behavior of interest groups, has received relatively little attention in the literature so far. Immergut (1992) states that groups' access to policy makers is shaped by political institutions, while Aspinwall \& Schneider (2000) suggest that institutional settings are important for understanding different political practices in different countries. Broscheid \& Coen (2003) theorize that policy makers build institutional structures which enable many interest groups to participate, because they prefer that various groups with diverging views provide inputs to the policy-making process. Yet so far, scholarly attention in this area has mostly focused on how the institutions of the EU influence interest group behavior (for a summary of this discussion see Dür, 2008). For instance, Beyers (2004) has empirically shown that such institutional differences matter for lobby groups at the EU level. We believe this institutional framework to be important at the country level as well. One of the few studies not focusing on the EU level by Kriesi et al. (2007) convincingly demonstrate that the national setting plays an important role for groups' action repertoires, and also show that different group types apply strategies differently. In this paper, we build on these findings by proposing that these two effects of the lobbying tactics one the one hand, and of the national institutional setting on the other, are conditional on each other.

\section{Group type and lobbying tactics}

Classifying interest groups and dividing them into valid subcategories is somewhat problematic (Binderkrantz, 2008). Various classification schemes have been proposed in the literature and applied in empirical research, e.g. specific interests versus diffuse interests (Schlozman \& 
Tierney; 1986, Kollman, 1998; Gais \& Walker, 1991), groups with corporative resources versus public interest groups (Binderkrantz, 2005, 2008), sectional and cause groups (Stewart, 1979; Klüver, 2012), or a distinction between business associations, professional associations, and citizen groups (Dür \& Mateo, 2013). These various classification schemes are, however, largely congruent with each other. Specific interest groups, sectional groups, and groups with corporative resources all represent a subsection of society. These groups represent the specific interests of their members, and they promote policies whose benefits accrue mostly to these members. Public interest groups and diffuse interest groups, on the other hand, are organizations pursuing goals in the common interest (or what they perceive as the common interest). Thus, their aim is not the (mostly monetary) benefit of their members, but the adoption of policies whose benefits accrue to non-members as well (Salisbury, 1969). We consider the term cause group to be slightly more general, since it also includes organizations interested in policies that benefit disadvantaged groups which are unable to organize themselves (e.g. drug addicts, asylum seekers, or handicapped people), rather than the general public. The differentiation between sectional and cause groups best serves the purpose of this paper, and thus this classification is adopted.

The literature suggests that group type is an important determinant of organizations' lobbying behavior (Maloney et al., 1994; Gais \& Walker, 1991; Binderkrantz, 2008; Dür \& Mateo, 2013). Cause groups, representing diffuse interests of the wider population, face a collective action problem. These groups constantly struggle to maintain their membership base, and to ensure their survival (Olson, 1965). For groups working on such issues, it is particularly important to constantly mobilize their membership base, and to inform the public regarding the issue in question. Only constant discussion and a build-up of peer pressure can solve the collective action problem (Brennan, 2009). Hence, outside lobbying strategies play a crucial role for cause groups, on the one hand to achieve their goals, but also to be noticed by the public, and to obtain scarce resources from potential new supporters (Gais \& Walker, 1991; Binderkrantz, 2008). 1

Specific interest groups, on the other hand, usually work on issues directly related to the wellbeing of their members, who tend to be much better informed about the issue in question, and are therefore much easier to mobilize (Lohmann, 1998). In addition, since business and professional associations are mainly concerned with the (monetary) benefits of their members, the results of their actions are more directly visible (to these members). Public and media campaigns to convince old members to stay, and new members to join, are therefore less important for specific interest groups. They therefore tend to employ fewer outside lobbying tactics (Dür \& Mateo, 2013). 
The second reason why cause groups rely more on outside lobbying tactics is that they are less integrated into the political process than specific interest groups (Della Porta \& Diani, 2006; Tilly, 1978). The reason for this, some authors suggest, is that specific interests are wellendowed with information linked to particular, well-defined policy areas, a resource highly valued by policy makers (Dür \& Mateo, 2012; Bouwen, 2004). In countries such as Switzerland and Germany, which are the subject of this study, this integration has even been institutionalized in the social partnership. Because the information provided through inside lobbying is generally less condensed and more technical (Austen-Smith, 1993), insider tactics tend to be better able to influence the decision making process (Grant, 1999; Mahoney, 2008). However, because cause groups often lack the direct access to policy makers that specific interest groups enjoy, they have no other option than to resort to outsider tactics to put pressure on policy makers.

H1: Specific interest groups rely more heavily on inside lobbying tactics than cause groups.

\section{$\underline{\text { Institutional settings and the interest group strategies }}$}

The institutional setting in which lobbying takes place also influences the mix of lobbying tactics that groups employ. Policy makers generally prefer information from a variety of sources, on the one hand to obtain a more complete picture of a policy issue, but also to counter the inherently strategic nature of the information provided by single interest organizations (Crombez, 2002). This means that cause groups are not completely excluded from the policy-making process, and also have insider tactics at their disposal. To what extent they are capable of gaining direct access to policy makers depends on the institutional setting. For instance, Beyers (2004) argues that the European Commission, which is only weakly controlled by other institutions and the general public, facilitates access for specific interest groups, but is a much more difficult lobbying target for cause groups. Members of the European Parliament, on the other hand, being elected officials, are much more susceptible to the arguments of cause groups, particularly if MEPs perceive them as representing the public interest.

Studying interest groups at the country level, Kriesi et al. (2007) show that Swiss groups behave differently from groups in other countries, and thus that the institutional setting influences interest group behavior. However, they do not demonstrate how this effect varies for different types of groups. We propose a specific way in which institutional settings influence the behavior of different types of lobby groups. Following Lijphart (1999) and Powell (2000), who theorize that electoral institutions are crucial for the policy making process, we suggest that direct (indirect) democracy has an impact on how accessible the policy making process is for different groups, but also on how much importance these groups attribute to public opinion. Direct 
democracy facilitates the access of cause groups to policy makers, and thus increases their use of insider tactics. However, direct democracy also forces sectional interest groups to pay more attention to the public opinion, and to justify their own position, since the constant threat of a referendum hangs over them. Thus, direct democracy has a moderating effect on both cause groups and specific interest groups regarding their mix of lobbying tactics, and we intend to test this effect by interacting group type with the electoral institutional setting.

The major reason for this expectation, following Papadopoulos $(1995,2001)$, is that the power balance in direct democracies is shifted towards outsiders. Hence, policy insiders, such as specific interest organizations, must pay much more attention to outsider interests and the public mood to either influence referendums, or to prevent them altogether. Hug (2004) and Matsusaka (2008) both show that the median voter's preference is better reflected in the policy making process when referendums can be prompted with relative ease by citizen groups or the opposition. Thus, political actors, who under different circumstances rely more heavily on secretive insider tactics, are forced to modify their behavior. More explicitly, specific interest groups have a strong incentive to voice and justify their views publicly, as their chances of winning the argument increase if they can win over the audience (Schattschneider, 1960). Therefore, in systems where direct democratic instruments and referendums are the norm, sectional interest groups are expected to be less reliant on direct access to policy makers, and to use outside lobbying tactics more widely. Conversely, because groups that would be outsiders in the absence of direct democracy now possess more power, their voices become more important. Forty years ago, Neidhart (1970) brought forward the now well-established proposition that the strongly consensual practices observed in Switzerland are, to a large degree, caused by direct democracy. A consequence of this consensual policy-making style is a more direct incorporation of a wide variety of parties and organizations into the policy making process. For these reasons, we expect the lobbying behavior of cause groups and specific interest groups to converge when direct democratic instruments are available.

There is a second, less positive view of the role interest groups play in Swiss referendums. Immergut (1992) states that interest-group-induced referendums have a tendency to be negative, and to be resistant to change. In other words, the main aim of many referendums is not to achieve goals by proposing new legislation, but instead to "threaten legislation" by calling for referendums when the proposed law is against the organizations' interests. According to Sartori (2005) this constitutes a "blackmailing potential" through direct democracy. Thus, interest groups act as gatekeepers of the referendum process, and mainly gain influence because of the tendency of referendums to reject legislation, not because they are actively integrated into, and positively contribute to the policy making process (Immergut, 1992). However, integrating 
organizations with such blackmailing potential into the early stages of the policy making process might help to mitigate potential future conflicts. Some convergence in the lobbying behavior of cause groups and specific interest groups should therefore also be expected if this second view is correct.

H2: When direct democratic instruments are easily available, cause groups are expected to rely relatively more on inside lobbying strategies, while sectional interest groups increase their use of outside lobbying strategies.

\section{Other factors influencing lobbying strategies}

There are other factors that influence how interest groups lobby, and we include these as control variables in the models below. Following Schlozman \& Tierney (1986), we include an organization's annual budget. Financial resources are expected to have an impact on both inside and outside lobbying tactics. The higher the spending power of organizations, the more they are able to invest in expensive inside and outside lobbying strategies, and the better they are able to diversify their tactics. However, although resource rich interest groups are able to increase spending on inside and outside lobbying strategies simultaneously, Dür \& Mateo (2013) find that the investment in insider tactics grows stronger as groups' resources increase.

Structural conditions, such as the institutional settings under scrutiny in this paper, have a strong influence on how interest groups operate. First, interest groups are faced with differing levels of competition, which influences their choice of lobbying tactics (Salisbury, 1990). According to Becker (1983) and Mahoney (2008), both insider and outsider strategies are affected by increased or decreased lobbying competition in a policy field. The second structural factor we control for is an organization's constituency, i.e. the members whose interests a group represents. ${ }^{2}$ Thrall (2006) shows empirically that groups with more (individual) members use outside lobbying strategies more frequently. Membership of individuals, however, is not the only form of membership: in most pressure organizations, other groups and firms can also become members. This form of membership is quite distinct from individual membership, e.g. a business organization with a few hundred members might almost attain full potential membership, while an environmental group with the same number of (individual) members might still be considered to be small. Membership of groups and firms is also associated with a different kind of lobbying behavior, namely one more focused on insider tactics. In addition, Olson (1965) suggests that a smaller group size facilitates overcoming the collective action problem. For these reasons, we differentiate between membership of groups, and membership of individuals, and we include separate measures for both these variables in the models below. In addition, 
mobilization must be understood as a top down process (Gais \& Walker, 1991), i.e. a group's leadership can decide whether to expand the membership base, or not. Some modern groups, however, are not interested in attracting (formal) members, but rather in gaining financial support from (sometimes temporary) supporters (Jordan \& Maloney, 2007). Such organizations might act entirely differently from membership-based groups. Therefore, we also include a measure of whether groups have members, or are member-less, in the models below. Finally, a number of authors (e.g. Baumgartner \& Leech, 2001; Mahoney, 2007, 2008) have convincingly demonstrated that the issue-area plays an important role for interest group's lobbying behavior. More specifically, Klüver (2011) demonstrates how issue-specific factors shape lobbying and lobbying success in the European Union. These three structural factors, competition, constituency, and issue area, are included as control variables in the statistical models below.

\section{Research Design}

To obtain data on lobbying behavior, we carried out a survey among interest groups in Switzerland and Germany. First, following the method suggested by Wonka et al. (2010), we compiled a list of interest groups for the two countries using various sources. ${ }^{3}$ During this coding process, we also registered the postal, internet, and email addresses of each organization's central office, and the internet and email addresses of the organization's communication departments (where possible). These email addresses were used as the emaildatabase for the online questionnaire. Data collection started in early 2011 in Switzerland, and in spring 2011 in Germany. The response rate was 40\% for Switzerland (985 of 2475 organizations) and 23\% for Germany (1246 of 5422 organizations). However, many organizations did not complete the questionnaire, or left important information blank. Particularly the questions regarding the organization's financial situation often remained unanswered. This resulted in a dataset of 584 Swiss and 543 German organizations who provided all the necessary information. ${ }^{4}$ Thus, relying on data from only German and Swiss interest organizations, we adopt a most similar systems design in this study. All data used in this paper, further described below, are derived from this survey dataset.

\section{Dependent variable}

The dependent variable of this study is constructed using the answers to our survey questions regarding interest groups' lobbying strategies. The participating groups from Germany and Switzerland had to indicate how important different target groups are for their lobbying activities. For each of these lobbying targets, respondents assigned values from 1 (no importance - target almost never or only very rarely contacted) to 5 (highly important - target is 
contacted very often). Survey participants had to indicate their lobbying activity regarding the following seven targets of lobbying: government and administration, political parties, news media, citizens/the public, members of the organization, other interest groups, and scientific organizations.

Factor analysis reveals that a smaller number of dimensions of lobbying activity underlie the seven basic variables. ${ }^{5}$ According to the Scree Test, two factors should be retrieved from the data. These factors seem to capture the standard typology often used in the literature, i.e. inside lobbying versus outside lobbying, relatively well. The variables 'Political Parties' and 'Government' load highly on the first factor (inside lobbying), while 'Members', 'Media', 'Citizens', and 'Interest Organizations' exhibit high loadings for the second factor (outside lobbying). There are, however, reasons not to simply obtain the factor scores for these two factors for further usage. First, 'Media' and 'Government' load relatively highly on both factors, hence there seems to be some overlap between the two dimensions. Second, the Kaiser criterion indicates that three factors are required. Indeed, when repeating the analysis with three factors, the pattern becomes clearer (see Figure 1). Again, 'Parties' (0.853) and 'Government' (0.759) load highly on the first factor (inside lobbying), while all other variables have low to very low factor loadings for inside strategies. The second factor (outside lobbying) is now mainly composed of 'Citizens' (0.796) and 'Media' (0.498). The third dimension instead consists mainly of 'Members' (0.454) and 'Other Organizations' (0.745). This last factor is therefore more a form of (internal and external) communication, and falls outside the insider/outsider lobbying spectrum of interest here. It will therefore not be further analyzed in this paper. When we repeat the analysis for Germany and Switzerland separately, we find the same three dimensions. 'Citizens' and 'Parties' have somewhat higher loadings in Switzerland than in Germany, while 'Government' exhibits a somewhat higher loading in Germany. Despite these small differences, this confirms that the dimensions in both countries, and in the overall sample, are the same. Thus, we proceed with the analysis of inside and outside lobbying from the pooled sample.

***** Figure 1 about here ${ }^{* * * * *}$

Now that it is confirmed that the variables 'Parties' and 'Government' capture inside lobbying, while the variables 'Media' and 'Citizens' represent outside lobbying, we proceed by creating the dependent variable. In the first step, the factor scores (from the three-way factor analysis) are retrieved for each organization in the model. In the second step, Factor 2 scores (outside lobbying) are subtracted from Factor 1 scores (inside lobbying). This produces a variable which indicates how heavily an organization relies on inside lobbying tactics compared to outside lobbying strategies. In other words, if the resulting value for a group is larger than zero, then this 
organization utilizes inside lobbying tactics more frequently than outside strategies. For values smaller than zero, the opposite is true.

The thus derived dependent variable is continuous instead of categorical (as the original variables used for the factor analysis are), with a mean of 0.06 , and a median of 0.17 . Hence, the average group attributes slightly more importance to inside lobbying than to outsider tactics. 616 of the organizations in the final dataset use more insider strategies, while 511 groups rely more on outside lobbying tactics. The standard deviation of 1.52 shows that there is considerable variation in how the interest groups in the final dataset lobby. Figure 2 provides a graphical representation of the dependent variable.

One problem this dependent variable faces is that an organization's level of lobbying activity is not taken into account. For instance, a group attaching high importance to both inside and outside lobbying, and scoring 2 and 2.5 on them, would have obtained the same value as a relatively inactive group which scores -1 and -0.5 . To avoid comparing apples and oranges, it is therefore crucial to control for the level of organizations' overall lobbying activity in the statistical models below.

***** Figure 2 about here ${ }^{* * * * *}$

\section{Independent variables}

Group type: No question in the survey allowed us to identify whether organizations are cause groups or specific interest groups. For this reason, all organizations which answered all relevant questions, and which could be identified through the information they provided (some organizations chose not to provide either internet or email address), were hand-coded. Of the 1270 organizations that replied to all questions needed for this paper, 1127 could be classified. The other 143 groups were either unidentifiable, or coders were too uncertain as to how to classify them. 338 cause groups were identified in the final dataset (154 from Switzerland, and 184 from Germany), and 631 specific interest groups (348 in Switzerland, 283 in Germany). Finally, following Binderkrantz (2008), we introduced an additional category called 'others' for organizations such as patient associations, scientific societies, religious organizations, and hobby groups. It is often unclear whether these groups are cause groups, or whether they mainly cater to the specific needs of their members. There is no clear expectation for this category, and thus no hypothesis on how they should behave, but we include the category in the models for exploratory reasons. 
Country: To account for institutional differences between Germany and Switzerland, we include a country dummy in all models. As indicated, there are 584 Swiss and 543 German interest groups in the final dataset. To test if direct democratic instruments really moderate the behavior of both cause groups and specific interest groups, this variable is interacted with the 'group type' variable.

Budget: Respondents to the survey were asked to provide their organization's annual budget, and we include the logarithm of this variable in all our models. This variable causes some concern, since 870 participants did not respond to this question, a much higher non-response rate than for any other question (only about 200 organizations did not reply to the question about corporate/group membership, the variable with the second highest number of missing answers). Thus, the question arises of whether excluding these 870 organizations may risk introducing systematic bias into the analysis. We check this by comparing the lobbying behavior of those groups who answered the budget question to those who avoided it, and we run Heckman selection models to account for the potential systematic bias (see results sections for more details).

Membership: Membership in interest organizations is divided into two categories: membership of individuals, and membership of other organizations and enterprises. Survey participants were asked to specify how many individual members their organizations have, and how many firms or organizations are registered members. The maximum individual membership in the dataset is $2,700,000$, for group membership the maximum is 650,000 . However, the median for individual membership is only 50 members, while the median for group membership is 13 . This indicates that the two variables are heavily skewed, and for this reason we take the logarithm of the two measures. Furthermore, to obtain comparable metrics for the two membership variables, we transform the logged values into z-scores. Thus, by construction, they have a mean of zero, and a standard deviation of one. Finally, 106 organizations in the dataset do not have any (formal) members. To control for the potentially very different lobbying behavior of such interest groups, we include a dummy variable indicating whether an organization is membership-based (1), or whether a group has no formal membership (0).

Competition: The variable capturing competition is a self-reported measure on a five-point scale ranging from 1 (very little competition) to 5 (very high competition). 218 of the organizations in the final dataset stated that they face very little to no competition, 694 said there is little competition in their field, 856 reported medium, 302 strong, and 68 very strong competition. 
Issue area: Participating groups in the survey were also asked to name their major issue-area of activity. Respondents could choose from eleven different issues, namely whether they mostly work on economic, social, health, leisure, cultural, education, scientific, religious, environmental general political, or other issues. By far the most organizations reported that they work on economic issues (354), followed by health issues (153), general political issues (117), and educational issues (113). Only 19 organizations work on religious issues, and merely three organizations were unable to find a suitable category and therefore chose the 'other issues' option.

Lobbying activity: As mentioned above, the dependent variables capture the relationship between an organization's use of insider versus outsider tactics, but without considering the overall lobbying activity of the group. Thus, very inactive groups potentially have the same value as very active groups. For instance, if a very active group heavily uses both insider and outsider strategies, its value will be close to zero, the same as for a group which uses both these tactics very rarely (in both cases, similar values cancel each other out by construction). We therefore construct a variable capturing lobbying activity by taking the mean of the four lobbying variables mentioned above (Government, Parties, Media, and Citizens). If an organization is highly active in lobbying all four target audiences, its value will be close to five (the maximum value), while very inactive organizations exhibit values close to one (the minimum). This activity variable is included in all reported models below as a control variable. Tables 1 and 2 report correlation coefficient and summary statistics for all dependent and independent variables used in this paper.

***** Table 1 about here $* * * * *$

***** Table 2 about here $* * * * *$

\section{Results}

In this section we present the empirical results. As mentioned above, there is reason to believe that there is some systematic bias in the data due to missing observations. For instance, those organizations which refused to provide their annual budget (or any of the other independent variables), but did answer the questions regarding their lobbying tactics, have a tendency to attach higher importance to all four lobbying targets analyzed in this paper. Lobbying political parties, for example, plays an important or very important role for $42.4 \%$ of the organizations in the final dataset, but does so for $50.3 \%$ of those groups who did not provide enough information to be included in the analysis. For lobbying the government, these numbers are $62.3 \%$ (groups in 
the models) versus $66.2 \%$ (groups not in the models), for lobbying the media the numbers are $50.3 \%$ versus $60.4 \%$, and for direct contact with citizens they are $22.9 \%$ versus $26.5 \%$. It is therefore conceivable that groups with certain characteristics are less willing to share their annual budget in a survey. If this selection is systematic, excluding these organizations from the analysis might lead to biased results. For this reason, we also include Heckman selection models in the analysis below. ${ }^{6}$ In addition, we run a full model and a partial model for both the OLS and the Heckman regressions. In models 1 and 3 we do not include the control variables 'competition', 'issue-area', and the membership dummy, since these variables exhibit only low levels of significance, and excluding them does not greatly affect the coefficients of interest in this paper. Table 3 summarizes the findings.

***** Table 3 about here $* * * * *$

First, note that the results are remarkably similar across all models. The differences between the full and partial OLS regressions are indeed negligible, and the two selection models also show remarkably similar results. However, the OLS and Heckman regressions show one noteworthy difference: individual membership, highly significant in both OLS models, drops below significance in the selection models. This indicates that some of the bias discussed above may have been removed.

\section{Groups' lobbying tactics in different institutional settings}

In this section we discuss the difference in the lobbying behavior of Swiss and German interest groups, the major topic of this paper. Cause groups serve as the base category in all the reported models, hence specific interest groups and the organizations in the 'others' category are directly comparable to cause groups. As can be seen, both coefficients for specific interest groups (the main effect and the interaction term), as well as the country dummy capturing the institutional setting, are significant across all models. In order to facilitate the interpretation, Figure 3 graphically illustrates this interaction between group type and institutional setting. The figure displays predicted values of lobbying behavior for the three types of Swiss and German interest groups at the mean of the covariates in Model 1, and their respective 95\% confidence intervals.

***** Figure 3 about here $* * * * *$

First, we discuss the results of Model 1 as conditional effects, as recommended by Brambor et al. (2005). Specific interest groups rely more heavily on insider tactics than cause groups in both Switzerland and Germany. The conditional effect of specific interests groups (compared to cause 
groups) for Switzerland is 0.413 , and is highly significant. Thus, in Switzerland, specific interest groups rely more heavily on insider tactics than cause groups, as predicted by hypothesis 1 . The picture is similar in Germany, yet the difference is much more pronounced. The conditional effect for specific interest groups in Germany is 0.839, about twice as large as in Switzerland. This effect is again highly significant, with a standard error of 0.130 . For Germany, this represents a difference almost as big as the distance from the median group's lobbying behavior to the tactical lobbying mix exhibited by groups at the first quartile, which is quite substantial. In other words, all else equal, specific interest groups invest much more in inside lobbying strategies than cause groups in both countries, yet the difference is much larger in Germany. This is a first indication that the convergence of lobbying tactics in Switzerland indeed takes effect, as hypothesized.

Interestingly, the difference in the observed lobbying behavior of interest groups in Germany and Switzerland is almost entirely due to cause groups, as the conditional effect of the institutional setting demonstrates. This conditional effect for Germany (compared to Switzerland) is estimated to be -0.390 for cause groups, and is again highly significant. This means that cause groups in Germany rely more strongly on outside lobbying tactics than their Swiss peers. Thus, as expected, direct democracy has a moderating effect on cause groups in Switzerland, and helps them to gain access to policy-makers more easily than in Germany. However, when we look at this conditional institutional effect for specific interest groups, we see that the effect is very close to zero at 0.036 , and not significant. Thus, the difference between the lobbying behavior of Swiss and German specific interest groups is negligible. The interest groups in the 'others' category behave very similarly to cause groups in both countries.

It is easier to understand this interaction term when looking at Figure 3, which shows these described effects graphically. We can clearly see that cause groups rely more strongly on outsider strategies than specific interest groups, as indicated by the smaller predicted values for these cause groups, in both countries (the more negative the predicted value, the more groups rely on outside lobbying, the more positive, the more they are expected to use insider tactics). Yet, in Switzerland, cause groups employ a relatively balanced mix of insider and outsider tactics, while their German peers rely much more on outsider strategies. This can be clearly seen in Figure 3, where Swiss cause groups are much closer to zero (at which point insider and outsider tactics are applied equally) than the German groups. The predicted values and confidence intervals of specific interest groups, on the other hand, are remarkably similar in both countries. Hence, the lobbying mix employed by specific interest groups does not appear to be affected by the institutional setting. 
This last result is very interesting concerning hypothesis 2 . We proposed two factors that might lead to a more moderate and balanced application of inside versus outside lobbying strategies in Switzerland. First, the increased importance of public opinion should force policy insiders, such as specific interest groups, to be more transparent, and thus to rely more heavily on outside lobbying than in settings where direct democracy is an exception. Second, the policy making process in Switzerland is designed to incorporate the opinion of a broader range of interest groups. Hence, cause groups are expected to be better integrated into the policy-making process, and therefore to make more use of insider tactics than in Germany. Our results indicate that only the second argument is substantiated: cause groups in Switzerland indeed apply a more mixed and balanced set of lobbying tactics. The overall hypothesis that the difference in the lobbying behavior of cause groups and specific interest groups is moderated, that they act more similarly to each other under conditions where referendums are likely, is substantiated. Yet this moderation is entirely driven by cause groups making use of easier access to decision makers, not by specific interest groups reaching out to the general public.

But why do we see the moderating effect of electoral institutions only for cause groups in Switzerland, and why do specific interest groups in Switzerland still rely as heavily on inside lobbying as in Germany. Earlier in this article, we introduced a less positive view of the Swiss referendum practice (see Immergut, 1992; Sartori, 2005). If this view is correct, and the capacity to call for a referendum mainly constitutes a blackmailing potential, then this might represent a means for policy outsiders to force their way into the system, and to gain access to policy makers. Thus, cause groups in Switzerland use the threat of calling a referendum as a tool to force their way into the political system, and are thus able to apply insider tactics more easily than cause groups in Germany. Specific interest groups, on the other hand, do not need this blackmailing potential, as gaining access to policy makers is easier for them even in the absence of referendums. Thus, there is no incentive for these groups to change their mix of lobbying tactics.

The question arises, however, whether our findings are evidence in favor of a causal link between electoral institution and interest group strategies, or whether something else is driving our results. In-depth interviews, conducted with twenty randomly chosen Swiss interest groups, reveal that direct contact with policy-makers is important to all types of groups, and that all interviewed groups are indeed in regular contact with politicians. The general assessment of policy-makers as important targets of lobbying applies to both cause groups and specific interest groups, such as employers' organization. Thus, it seems that insider tactics are indeed very important for all types of groups in Switzerland. However, in our qualitative interviews we did not directly ask the interview partners whether the referendum process helped them to gain 
access to politicians. Nevertheless, a relatively small cause group stated in an interview that it derived most of its power from the referendum process. Although the group has lost all referendums to date, the various campaigns have helped to bring the group to the attention of a larger audience [1]. ${ }^{7}$ This allowed the group to take their concerns directly to policy-makers and to parliament. Another small cause group stated that they were "a hundred percent convinced that we are able to influence politics", and that the best evidence for this came from the "various recent referendums" led by the group [2]. This is additional evidence in favor of our quantitative results that cause groups in Switzerland are better able to use insider tactics due to the referendum process, and that the threat of calling referenda indeed constitutes the described blackmailing potential.

Can we also find evidence in the interviews for why the lobbying behavior of specific interest groups is not greatly affected by direct democratic instruments? One reason might be that the topics subject to referendums are more important for cause groups, and less so for specific interest groups. However, in the interviews, the latter groups repeatedly referred to the significance of referendums for their communication departments. We would therefore rule out that specific interests are simply less affected by direct democracy. However, one large employer's organization stated that referendum campaigns are not usually conducted under their own name. Instead, campaigns are managed by specifically appointed committees, and are usually headed by well-known politicians [3]. Outside lobbying via the media, poster campaigns, or direct contact with voters then occurs under the name of the committee, and not the name of the specific interest group actually financing the campaign. We encountered a similar pattern in another interview with a relatively small pro-business group based in Zurich. The group is funded by businesses and employers' organizations, and is responsible for running various probusiness campaigns in repeated referendums on behave of these donors. Indeed, the group was first established as such a committee as just described, but "because it became apparent that there were referendums again and again, [the committee] was continuously sustained. Then the group was established [out of the committee], in order to give it a legal structure" [4]. This "outsourcing" of outsider lobbying might be the reason why Swiss specific interest groups do not exhibit the expected moderation of their lobbying strategies. We consider this to be a promising topic for future research.

Finally, it can be disputed to which extent our findings are generalizable. The Swiss case is very specific, as it is the only country which uses referendums frequently. On the other hand, there are many countries like Germany, with a much more limited use of referendums. Thus, we posit that the lobbying tactics of cause groups and specific interest groups differ widely in countries like Germany, and that this difference reflects a) the structural imbalance between these group 
types, and b) the easier access to decision makers specific interest groups enjoy in representative democracies. However, we acknowledge that more research in that area, with a larger number of country cases, is in order.

\section{Conclusion}

In this article we sought to show that the institutional settings in which lobbying organizations work have an impact on which mix of lobbying tactics they employ. We find that in settings where direct democratic instruments are easily available, as in the Swiss case, cause groups are much better integrated into the policy making process, and therefore use a more balanced mix of lobbying tactics. In other words, Swiss cause groups use inside lobbying strategies almost as often as outsider tactics, while their German counterparts rely much more heavily on the outsider strategies of seeking influence via the media, or by directly trying to mobilize the public.

For specific interest groups, on the other hand, no such moderating effect is found. We hypothesized that groups, that under normal circumstances prefer more secretive insider tactics, would have an incentive to appeal directly to the public in Switzerland, to show that the public interest is important to them, but also to publicize why they stand for certain policy positions. We reasoned that if a referendum could not be averted, having bad relations with the public, and no pre-formulated and communicated positions, might disadvantage such groups. However, this effect could not be found in the data. Swiss specific interest groups rely just as heavily on inside lobbying strategies as their German peers. Thus, the effect direct democracy has on the mix of lobbying tactics interest groups employ is almost entirely driven by the inclusion of cause groups into the policy making process, not by forcing specific interest groups to seek the public eye. We believe we cannot find this moderating effect for specific interest groups, because these groups do not need the blackmailing potential referendums provide, since they gain access to policy makers more easily even in the absence of referendums.

In both countries, however, there is still a pronounced difference in how cause groups and specific interest groups behave. Although the difference is much smaller in Switzerland, cause groups still apply a mix more heavy in outside lobbying, while specific interest groups prefer insider tactics. In Germany, this preference on the part of cause groups for outside lobbying strategies is very pronounced. In the absence of direct democratic means to call a referendum, and the subsequent exclusion from the policy making process, German cause groups have no other option than to put pressure on policy makers via mass media, and by rallying support from the public for their cause. 
As noted above, the Swiss case is very specific, which limits the generalizability of our results. The German findings, however, are in our view not only interesting, but also highly relevant. Germany is not a special case with respect to referendums. Hence, if our argument that cause groups are generally more excluded from the policy making process than specific interest groups in countries like Germany is valid, this has important implications for the democratic process in such countries. For this reason, it would be desirable to study whether this finding holds in different countries and with different degrees of direct democracy.

\section{Acknowledgements}

This article draws on work conducted within the framework of the interdisciplinary research project 'NCCR Democracy', funded by the Swiss National Science Foundation. We thank Stefanie Bailer, Anne Binderkrantz, Patrick Donges, Ottfried Jarren, Heike Klüver, Dorothea Putscher, as well as three anonymous reviewers for their assistance and for helpful comments.

\section{References}

Aspinwall, M. \& Schneider, G. (2000). Same menu, separate tables: The institutionalist turn in political science and the study of European integration. European Journal of Political Research, 39(1): 1-36.

Austen-Smith, D. (1993). Information and influence: Lobbying for agendas and votes. American Journal of Political Science, 37(3): 799-833.

Austen-Smith, D. \& Wright, J. R. (1992). Competitive lobbying for a legislator's vote. Social Choice and Welfare, 9(3): 229-257.

Baumgartner, F. \& Leech, B. (1998). Basic interests: The importance of groups in politics and in political science. Cambridge: Cambridge Universiy Press.

Baumgartner, F. R. \& Leech, B. L. (2001). Interest niches and policy bandwagons: Patterns of interest group involvement in national politics. Journal of Politics, 63(4): 1191-1213.

Beauducel, A. \& Herzberg, P. Y. (2006). On the performance of maximum likelihood versus means and variance adjusted weighted least squares estimation in CFA. Structural Equation Modeling, 13(2): 186-203. 
Becker, G. S. (1983). A theory of competition among pressure groups for political influence. The Quarterly Journal of Economics, 98(3): 371-400.

Beyers, J. (2004). Voice and access: Political practices of European interest associations. European Union Politics, 5(2): 211-240.

Binderkrantz, A. (2005). Interest group strategies: Navigating between privileged access and strategies of pressure. Political Studies, 53(4): 694-715.

Binderkrantz, A. (2008). Different groups, different strategies: How interest groups pursue their political ambitions. Scandinavian Political Studies, 31(2): 173-200.

Binderkrantz, A. \& Krøyer, S. (2012). Customizing strategy: Policy goals and interest group strategies. Interest Groups \& Advocacy, 1(1): 115-138.

Bouwen, P. (2004). Exchanging access goods for access: A comparative study of business lobbying in the European Union institutions. European Journal of Political Research, 43(3): 337369.

Brambor, T., Clark, W., \& Golder, M. (2006). Understanding interaction models: Improving empirical analysis. Political Analysis, 14(1): 63-82.

Brennan, G. (2009). Climate change: A rational choice politics view. The Australian Journal of Agriculture and Resource Economics, 53(3): 309-326.

Broscheid, A. \& Coen, D. (2003). Insider and outsider lobbying of the European Commission: An informational model of forum politics. European Union Politics, 4(3): 165-189.

Crombez, C. (2002). Information, lobbying and the legislative process in the European Union. European Union Politics, 3(1): 7-32.

Della Porta, D. \& Diani, M. (2006). Social movements: An introduction. Oxford: Blackwell Publishing.

Dür, A. (2008). Interest groups in the European Union: How powerful are they? West European Politics, 31(6): 1212-1230. 
Dür, A. \& Mateo, G. (2012). Who lobbies the European Union? National interest groups in a multilevel polity. Journal of European Public Policy, 19(7): 969-987.

Dür, A. \& Mateo, G. (2013). Gaining access or going public? Interest group strategies in five European countries. European Journal of Political Research, 52(5): 660-686.

Gais, T. \& Walker, J. (1991). Pathways to influence in American politics. In J. Walker (ed.), Mobilizing interest groups in America: Patrons, professions, and social movements. Ann Arbor: University of Michigan Press: 103-122.

Grant, W. (1999). Pressure groups and British politics. London: Macmillan.

Hansen, J. M. (1991). Gaining access: Congress and the farm lobby, 1919-1981. London: University of Chicago Press.

Holyoke, T. T. (2003). Choosing battlegrounds: Interest group lobbying across multiple venues. Political Research Quarterly, 56(3): 325-336.

Holyoke, T. T. (2009). Interest group competition and coalition formation. American Journal of Political Science, 53(2): 360-375.

Hug, S. (2004). Occurrence and policy consequences of refrendums: A theoretical model and empirical evidence. Journal of Theoretical Politics, 16(3): 321-356.

Immergut, E. (1992). Health politics: interests and institutions in Western Europe. Cambridge: Cambridge University Press.

Jordan, G. \& Maloney, W. (2007). Democracy and interest Groups. Enhancing participation? New York: Palgrave Macmillan.

Jöreskog, K. G. \& Moustaki, I. (2001). Factor analysis of ordinal variables: A comparison of three approaches. Multivariate Behavioral Research, 36(3): 347-387.

Keeter, S., Kennedy, C., Dimock, M., Best, J. \& Craighill, P. (2006). Gauging the impact of growing nonresponse on estimates from a national RDD telephone survey. Public Opinion Quarterly, 70(5): 759-779. 
Klüver, H. (2011). The contextual nature of lobbying: Explaining lobbying success in the European Union. European Union Politics: 483-506.

Klüver, H. (2012). Biasing politics? Interest group participation in EU policy-making. West European Politics, 35(5): 1114-1133.

Kollman, K. (1998). Outside lobbying: Public opinion and interest group strategies. Princeton: Princeton University Press.

Kriesi, H., Tresch, A. \& Jochum, A. (2007). Going public in the European Union. Action repertoirs of Western European collective political actors. Comparative Political Studies, 40(1): 48-73.

Lijphart, A. (1999). Patterns of democracy: Government forms and performance in thirty-six countries. New Haven: Yale University Press.

Lohmann, S. (1995). Information, access, and contributions: A signaling model of lobbying. Public Choice, 85(3-4): 267-284.

Lohmann, S. (1998). An information rationale for the power of special interests. American Political Science Review, 92(4): 809-827.

Lowery, D. \& Gray, V. (2004). Bias in the heavenly chorus: Interests in society and before government. Journal of Theoretical Politics, 16(1): 5-29.

Mahoney, C. (2007). Lobbying success in the United States and the European Union. Journal of Public Policy, 27(1): 35-56.

Mahoney, C. (2008). Brussels versus the Beltway: Advocacy in the United States and the European Union. Washington, DC: Georgetown University Press.

Maloney, W. A., Jordan, G. \& McLaughlin, A. M. (1994). Interest groups and public policy: The insider/outsider model revisited. Journal of Public Policy, 14(1): 17-38.

Matsusaka, J. G. (2008). For the many or the few: The initiative, public policy, and American democracy. Chicago: University of Chicago Press. 
Neidhart, L. (1970). Plebiszit und pluralitäre Demokratie: eine Analyse der Funktion des Schweizerischen Gesetzesreferendums. Bern: Francke.

Oeckl, A. (2009). Taschenbuch des Öffentlichen Lebens - Deutschland 2010. Bonn: Festland Verlag. Olson, M. (1965). The logic of collective action. Public goods and the theory of groups. Cambridge, London: Harvard University Press.

Papadopoulos, Y. (1995). Analysis of functions and dysfunctions of direct democracy: Top-down and bottom-up perspectives. Politics \& Society, 23(4): 421-448.

Papadopoulos, Y. (2001). How does direct democracy matter? The impact of referendum votes on politics and policy-making. West European Politics, 24(2): 35-58.

Potters, J. \& van Winden, F. (1990). Modelling political pressure as transmission of information. European Journal of Political Economy, 6(1): 61-88.

Powell, G. B. (2000). Elections as instruments of democracy: Majoritarian and proportional visions. New Haven: Yale University Press.

Salisbury, R. H. (1969). An exchange theory of interest groups. Midwest Journal of Political Science, 13(1): 1-32.

Salisbury, R. H. (1990). The paradox of interest groups in Washington - more groups, less clout. In A. J. King (ed.), The New American Political System. Washington, DC: American Enterprise Institute: 203-230.

Sartori, G. (2005). Parties and party systems: A framework for analysis. Colchester: ECPR Press.

Schattschneider, E. E. (1960). The semisovereign people. New York: Holt, Rinehart and Winston.

Schlozman, K. L. \& Tierney, J. T. (1986). Organized interests and American democracy. New York: Harper \& Row.

Schwabe (2009). Publicus 2010. Schweizer Jahrbuch des öffentlichen Lebens. Basel: Schwabe Basel. 
Stewart, J. D. (1979). British pressure groups: Their role in relation to the House of Commons. Oxford: Greenwood Press.

Thrall, T. (2006). The myth of the outside strategy: Mass media news coverage of interest groups. Political Communication, 23(4): 407-420.

Tilly, C. (1978). From mobilization to revolution. New York: McGraw-Hill.

Truman, D. (1951). The governmental process. Political interests and public opinion. Westport: Greenwood Press.

Wonka, A., Baumgartner, F. R., Mahoney, C. \& Berkhout, J. (2010). Measuring the size and scope of the EU interest group population. European Union Politics, 11(3): 463-476. 
Table 1: Correlation table for the dependent and independent variables

\begin{tabular}{|c|c|c|c|c|c|c|c|c|c|c|}
\hline & 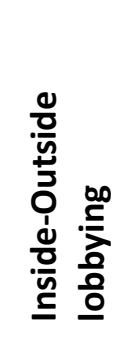 & 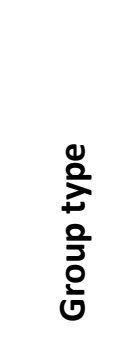 & 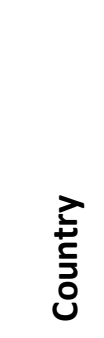 & 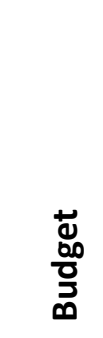 & 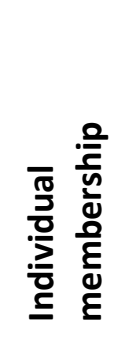 & 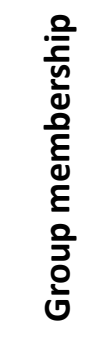 & & 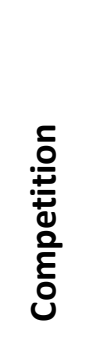 & $\begin{array}{l}\stackrel{0}{\vec{y}} \\
\underline{\underline{y}}\end{array}$ & 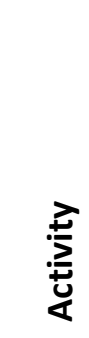 \\
\hline Inside-Outside lobbying & 1.00 & & & & & & & & & \\
\hline Group type & -0.01 & 1.00 & & & & & & & & \\
\hline Country & -0.03 & -0.06 & 1.00 & & & & & & & \\
\hline Budget & 0.22 & -0.12 & -0.09 & 1.00 & & & & & & \\
\hline Individual members. (log, scaled) & -0.13 & 0.04 & 0.02 & -0.02 & 1.00 & & & & & \\
\hline Group membership (log, scaled) & 0.13 & 0.07 & 0.02 & 0.21 & -0.16 & 1.00 & & & & \\
\hline Membership dummy & -0.04 & 0.04 & 0.04 & -0.13 & 0.35 & 0.34 & 1.00 & & & \\
\hline Competition & 0.19 & -0.08 & 0.04 & 0.18 & -0.04 & 0.07 & -0.02 & 1.00 & & \\
\hline Issue & -0.04 & -0.16 & 0.03 & -0.02 & 0.09 & -0.01 & 0.04 & 0.00 & 1.00 & \\
\hline Activity & 0.31 & -0.21 & 0.14 & 0.29 & 0.05 & 0.06 & -0.00 & 0.32 & 0.08 & 1.00 \\
\hline
\end{tabular}

Table 2: Summary statistics for the dependent and independent variables

\begin{tabular}{lccccc}
\hline Variable name & Obs. & Mean & St. dev. & Min. & Max. \\
\hline Inside-Outside lobbying & 1127 & 0.06 & 1.52 & -5.24 & 4.66 \\
Group type & 1127 & & & $1(338)$ & $3(158)$ \\
Country & 1127 & & & $0(584)$ & $1(543)$ \\
Budget (log) & 1127 & 12.47 & 2.16 & 6.91 & 20.50 \\
Individual membership (log, scaled) & 1127 & 0 & 1 & -1.02 & 3.21 \\
Groups membership (log, scaled) & 1127 & 0 & 1 & -0.96 & 4.50 \\
Membership dummy & 1127 & & & $0(106)$ & $1(1021)$ \\
Competition & 1127 & & & $1(121)$ & $5(32)$ \\
Issue & 1127 & & & $1(354)$ & $11(3)$ \\
Activity & 1127 & 3.29 & 0.85 & 1 & 5 \\
\hline
\end{tabular}


Table 3: Results from the OLS and Heckman Selection Models

\begin{tabular}{|c|c|c|c|c|}
\hline & \multicolumn{4}{|c|}{ Dependent variable: Inside-Outside Lobbying } \\
\hline & $\begin{array}{l}\text { OLS partial } \\
\text { model }\end{array}$ & $\begin{array}{l}\text { OLS full } \\
\text { model }\end{array}$ & $\begin{array}{c}\text { Heckman } \\
\text { partial } \\
\text { model }\end{array}$ & $\begin{array}{l}\text { Heckman } \\
\text { full model }\end{array}$ \\
\hline & $(1)$ & (2) & (3) & (4) \\
\hline \multicolumn{5}{|l|}{ Group Type (Ref. = Cause groups) } \\
\hline Specific interest groups & $\begin{array}{c}0.413 * * * \\
(0.134)\end{array}$ & $\begin{array}{c}0.349 * * \\
(0.145)\end{array}$ & $\begin{array}{c}0.416 * * * \\
(0.133)\end{array}$ & $\begin{array}{c}0.351^{* *} \\
(0.143)\end{array}$ \\
\hline Other groups & $\begin{array}{l}-0.040 \\
(0.191)\end{array}$ & $\begin{array}{c}0.161 \\
(0.218)\end{array}$ & $\begin{array}{c}-0.040 \\
(0.191)\end{array}$ & $\begin{array}{c}0.168 \\
(0.219)\end{array}$ \\
\hline \multicolumn{5}{|l|}{ Institutional setting (Ref=CH) } \\
\hline No direct dem. (D) & $\begin{array}{c}-0.390 * * \\
(0.153)\end{array}$ & $\begin{array}{c}-0.375^{* *} \\
(0.153)\end{array}$ & $\begin{array}{c}-0.389 * * \\
(0.152)\end{array}$ & $\begin{array}{c}-0.387 * * \\
(0.150)\end{array}$ \\
\hline \multicolumn{5}{|l|}{ Interaction terms } \\
\hline Specific interests * country dummy & $\begin{array}{c}0.426 * * \\
(0.187)\end{array}$ & $\begin{array}{c}0.442^{* *} \\
(0.187)\end{array}$ & $\begin{array}{c}0.420^{* *} \\
(0.186)\end{array}$ & $\begin{array}{c}0.453^{* *} \\
(0.184)\end{array}$ \\
\hline Others * country dummy & $\begin{array}{c}0.086 \\
(0.267)\end{array}$ & $\begin{array}{c}0.085 \\
(0.271)\end{array}$ & $\begin{array}{c}0.070 \\
(0.267)\end{array}$ & $\begin{array}{c}0.082 \\
(0.275)\end{array}$ \\
\hline Budget (log) & $\begin{array}{c}0.070 * * * \\
(0.021)\end{array}$ & $\begin{array}{c}0.066 * * * \\
(0.021)\end{array}$ & $\begin{array}{c}0.064 * * * \\
(0.021)\end{array}$ & $\begin{array}{c}0.062^{* * *} \\
(0.021)\end{array}$ \\
\hline Individual membership (log, scaled) & $\begin{array}{c}-0.168^{* * *} \\
(0.044)\end{array}$ & $\begin{array}{c}-0.155^{* * *} \\
(0.050)\end{array}$ & $\begin{array}{l}-0.091 \\
(0.092)\end{array}$ & $\begin{array}{l}-0.020 \\
(0.131)\end{array}$ \\
\hline Group membership (log, scaled) & $\begin{array}{c}0.113 * * * \\
(0.043)\end{array}$ & $\begin{array}{l}0.081^{*} \\
(0.049)\end{array}$ & $\begin{array}{c}0.164^{* *} \\
(0.068)\end{array}$ & $\begin{array}{l}0.154^{*} \\
(0.091)\end{array}$ \\
\hline Lobbying activity & $\begin{array}{c}0.370 * * * \\
(0.038)\end{array}$ & $\begin{array}{c}0.333^{* * *} \\
(0.041)\end{array}$ & $\begin{array}{c}0.332 * * * \\
(0.058)\end{array}$ & $\begin{array}{c}0.246^{* * *} \\
(0.089)\end{array}$ \\
\hline Constant & $\begin{array}{c}-2.097^{* * *} \\
(0.283)\end{array}$ & $\begin{array}{c}-2.176^{* * *} \\
(0.382)\end{array}$ & $\begin{array}{c}-2.992 * * * \\
(0.823)\end{array}$ & $\begin{array}{c}-4.253^{* * *} \\
(1.455)\end{array}$ \\
\hline \multicolumn{5}{|l|}{ Additional controls: } \\
\hline Competition & No & Yes & No & Yes \\
\hline Issues & No & Yes & No & Yes \\
\hline Membership dummy & No & Yes & No & Yes \\
\hline Observations & 1,127 & 1,127 & 1,941 & 1,941 \\
\hline $\mathbf{R}^{2}$ & 0.189 & 0.214 & 0.189 & 0.214 \\
\hline Adjusted $\mathbf{R}^{2}$ & 0.182 & 0.196 & 0.182 & 0.197 \\
\hline Rho & & & 0.821 & 0.763 \\
\hline Inverse Mills Ratio & & & $1.44(1.41)$ & $1.26(1.37)$ \\
\hline Residual Std. Error & 1.373 & 1.361 & & \\
\hline F-Statistic & $28.83 * * *$ & $12.47^{* * *}$ & & \\
\hline
\end{tabular}




\begin{tabular}{|c|c|c|c|c|}
\hline & \multicolumn{4}{|c|}{ Dependent variable: Inside-Outside Lobbying } \\
\hline & $\begin{array}{l}\text { OLS partial } \\
\text { model }\end{array}$ & $\begin{array}{l}\text { OLS full } \\
\text { model }\end{array}$ & $\begin{array}{c}\text { Heckman } \\
\text { partial } \\
\text { model }\end{array}$ & $\begin{array}{l}\text { Heckman } \\
\text { full model }\end{array}$ \\
\hline & $(1)$ & (2) & (3) & $(4)$ \\
\hline \multicolumn{5}{|l|}{ Group Type (Ref. = Cause groups) } \\
\hline Specific interest groups & $\begin{array}{c}0.413 * * * \\
(0.134)\end{array}$ & $\begin{array}{c}0.349 * * \\
(0.145)\end{array}$ & $\begin{array}{c}0.416 * * * \\
(0.133)\end{array}$ & $\begin{array}{c}0.351^{* *} \\
(0.143)\end{array}$ \\
\hline Other groups & $\begin{array}{l}-0.040 \\
(0.191)\end{array}$ & $\begin{array}{c}0.161 \\
(0.218)\end{array}$ & $\begin{array}{c}-0.040 \\
(0.191)\end{array}$ & $\begin{array}{c}0.168 \\
(0.219)\end{array}$ \\
\hline \multicolumn{5}{|l|}{ Institutional setting (Ref.=CH) } \\
\hline No direct democracy (D) & $\begin{array}{c}-0.390^{* *} \\
(0.153)\end{array}$ & $\begin{array}{c}-0.375^{* *} \\
(0.153)\end{array}$ & $\begin{array}{c}-0.389 * * \\
(0.152)\end{array}$ & $\begin{array}{c}-0.387^{* *} \\
(0.150)\end{array}$ \\
\hline \multicolumn{5}{|l|}{ Interaction terms } \\
\hline Specific interests * country dummy & $\begin{array}{c}0.426^{* *} \\
(0.187)\end{array}$ & $\begin{array}{c}0.442 * * \\
(0.187)\end{array}$ & $\begin{array}{c}0.420^{* *} \\
(0.186)\end{array}$ & $\begin{array}{c}0.453^{* *} \\
(0.184)\end{array}$ \\
\hline Others * country dummy & $\begin{array}{c}0.086 \\
(0.267)\end{array}$ & $\begin{array}{c}0.085 \\
(0.271)\end{array}$ & $\begin{array}{c}0.070 \\
(0.267)\end{array}$ & $\begin{array}{c}0.082 \\
(0.275)\end{array}$ \\
\hline Budget (log) & $\begin{array}{c}0.070 * * * \\
(0.021)\end{array}$ & $\begin{array}{c}0.066 * * * \\
(0.021)\end{array}$ & $\begin{array}{c}0.064 * * * \\
(0.021)\end{array}$ & $\begin{array}{c}0.062^{* * *} \\
(0.021)\end{array}$ \\
\hline Individual membership (log, scaled) & $\begin{array}{c}-0.168^{* * *} \\
(0.044)\end{array}$ & $\begin{array}{c}-0.155^{* * *} \\
(0.050)\end{array}$ & $\begin{array}{l}-0.091 \\
(0.092)\end{array}$ & $\begin{array}{l}-0.020 \\
(0.131)\end{array}$ \\
\hline Group membership (log, scaled) & $\begin{array}{c}0.113 * * * \\
(0.043)\end{array}$ & $\begin{array}{l}0.081^{*} \\
(0.049)\end{array}$ & $\begin{array}{c}0.164^{* *} \\
(0.068)\end{array}$ & $\begin{array}{l}0.154^{*} \\
(0.091)\end{array}$ \\
\hline Lobbying activity & $\begin{array}{c}0.370 * * * \\
(0.038)\end{array}$ & $\begin{array}{c}0.333 * * * \\
(0.041)\end{array}$ & $\begin{array}{c}0.332 * * * \\
(0.058)\end{array}$ & $\begin{array}{c}0.246^{* * *} \\
(0.089)\end{array}$ \\
\hline \multicolumn{5}{|l|}{ Competition (Ref. = Very low comp.) } \\
\hline Low competition & & $\begin{array}{c}0.088 \\
(0.144)\end{array}$ & & $\begin{array}{c}0.097 \\
(0.146)\end{array}$ \\
\hline Medium competition & & $\begin{array}{c}0.385 * * * \\
(0.146)\end{array}$ & & $\begin{array}{c}0.388^{* * *} \\
(0.147)\end{array}$ \\
\hline Strong competition & & $\begin{array}{c}0.390^{* * *} \\
(0.171)\end{array}$ & & $\begin{array}{c}0.403 * * * \\
(0.170)\end{array}$ \\
\hline Very strong competition & & $\begin{array}{l}-0.042 \\
(0.278)\end{array}$ & & $\begin{array}{l}-0.023 \\
(0.273)\end{array}$ \\
\hline \multicolumn{5}{|l|}{ Issue (Ref. = Economic issues) } \\
\hline Social issues & & $\begin{array}{l}-0.213 \\
(0.182)\end{array}$ & & $\begin{array}{l}-0.208 \\
(0.180)\end{array}$ \\
\hline Health issues & & $\begin{array}{c}-0.372^{* * *} \\
(0.141)\end{array}$ & & $\begin{array}{c}-0.369 * * * \\
(0.138)\end{array}$ \\
\hline Leisure issues & & $\begin{array}{c}-0.428 * * \\
(0.197)\end{array}$ & & $\begin{array}{c}-0.445^{* *} \\
(0.198)\end{array}$ \\
\hline Cultural issues & & $\begin{array}{c}-0.444 * * \\
(0.185)\end{array}$ & & $\begin{array}{c}-0.440^{* *} \\
(0.185)\end{array}$ \\
\hline Educational issues & & $\begin{array}{c}0.100 \\
(0.152)\end{array}$ & & $\begin{array}{c}0.105 \\
(0.152)\end{array}$ \\
\hline Scientific issues & & $\begin{array}{l}-0.211 \\
(0.206)\end{array}$ & & $\begin{array}{l}-0.196 \\
(0.207)\end{array}$ \\
\hline
\end{tabular}


Religious issues

Environmental issues

General political issues

Other issues
$-0.359$

(0.334)

$-0.012$

$(0.158)$

$-0.104$

(0.204)

1.030

(0.793)
$-0.359$

$(0.337)$

$-0.003$

$(0.150)$

$-0.104$

(0.205)

1.040

(0.816)

Membership dummy (Ref. $=$ No members)

Orgs. With members

$0.095 \quad 0.392 *$

(0.171)

(0.211)

Constant

$-2.097 * * *$

$-2.176^{* * *}$

$-2.992 * * *$

$-4.253 * * *$

\section{Observations}

(0.283)

(0.382)

1,127

(0.823)

(1.455)

$\mathbf{R}^{2}$

Adjusted $\mathbf{R}^{2}$

0.189

0.214

1,941

1,941

Rho

0.182

0.196

0.189

0.216

0.182

0.198

Inverse Mills Ratio

Residual Std. Error

0.821

1.145

F-Statistic

1.373

$1.44(1.41)$

$3.20(2.27)$

Note: Standard errors in parentheses

$28.83^{* * *} \quad 12.47^{* * *}$

$* p<0.1 ; * * p<0.05 ; * * * p<0.01$ 
${ }^{1}$ We include two control variables to account for individual membership and membership of firms and groups in the models below. Furthermore, we acknowledge that informal membership might play a role for the level of influence groups attain. Unfortunately, we do not have a way to measure quasi-membership.

${ }^{2}$ Cause groups often fight for a common cause that benefits the public beyond their own membership base. However, here we only understand constituency as those individuals or groups that directly support an interest organization.

${ }^{3}$ For Germany, we used two sources: The "Taschenbuch des öffentlichen Lebens - Deutschland 2010" (Oeckl, 2009), and the official registry of organizations with the German Bundestag. In Switzerland we use the "Schweizer Jahrbuch des öffentlichen Lebens" (Schwabe, 2009). In addition, we screened the parliament's "Gästeregister" (guest registry) for relevant organizations. Finally, we checked the website www.verbaende.ch for potentially relevant organizations not yet included in our list.

${ }^{4}$ The overall response rate of $28.3 \%$ is not too far removed from similar projects. Keeter et al. (2006) have shown that increasing the response rate from $25 \%$ to $50 \%$ does not yield significantly different results. After deleting the incomplete cases, we are left with final rates of $23.5 \%$ for Switzerland, and $10.1 \%$ for Germany.

${ }^{5}$ Some authors believe that with categorical variables, factor analysis can be problematic (Jöreskog \& Moustaki, 2001). However, Beauducel \& Herzberg (2006) show that simple maximum likelihood (ML) approaches work well when the variables have at least four categories. In addition, inside and outside lobbying tactics are not independent of each other. Interest groups tend to increase or decrease their use of different lobbying tactics simultaneously, as all of our seven variables capturing lobbying strategies are correlated. Thus, in contrast to Dür \& Mateo (2013), who use an orthogonal solution, we opt for an oblique rotation method to allow for this theoretically derived correlation of the factors.

${ }^{6}$ We assume that resource-rich groups are particularly reluctant to provide their annual budget. Hence, budget should be included in the selection stage, but this would result in the loss of the same observations as in the OLS models. Therefore, we use total membership as a proxy for resource wealth, and we also include a squared term for total membership in the selection stage (assuming the reluctance to answer the budget question grows as wealth increases, but at a decreasing rate). In the models below, the selection stage coefficients are not reported. They will be provided to interested readers on request.

7 The interviews were conducted as part of a bigger project on the lobbying and communication behavior of Swiss and German interest groups. The numbers in squared brackets identify our interview partners. Because we granted the interviewees anonymity, we only identify them by numbers. The complete transcripts of the interviews (in German) are available from the authors. 